\section{PS-054-1 胸壁発生の有荃性気管支性囊胞の一例}

\author{
${ }^{1}$ 日本医科大学武蔵小杉病院外科 - 心臟血管外科, ${ }^{2}$ 日本医科大学付属病院外 \\ 科学
}

木下 裕康 ${ }^{1}$, 原口 秀司 ${ }^{1}$, 保科 淑子 ${ }^{1}$, 冨田 剛志 ${ }^{1}$, 日置 正文 ${ }^{1}$, 小泉 潔, 清水 一雄 ${ }^{2}$

気管支性囊胞は胎生期原始前腸由来で, 発生過程の形成異常による先天性疾 患である，傍気管や肺門に発生することが多いとされているが，今回我々は， 胸壁発生の有茎性気管支性囊胞の症例を経験したので報告する.

症例は21歳, 男性. 06 年5月の学校検診で右肺異常陰影を指摘され, 当院に 紹介された. 胸部単純写真 (立位)で, 第10肋骨後方に心陰影に接してシルエ ットサイン陰性の腫瘤影を認めた. 胸部 CT (仰臥位) で第9肋骨後方右胸壁 に接して，体位に変動する境界明瞭で内部均一の低密度の $31 \times 15 \mathrm{~mm}$ の腫瘤 影を認めた，MRIでは，T1強調で筋肉よりやや低信号，T2強調で高信号で

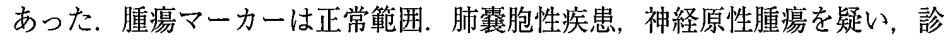
断確定・治療目的で手術の方針とした. 胸腔鏡下 (3ポート), 腫瘍摘出術を 施行した，病変は椎体前壁側胸膜から有茎性に連続する囊胞で, 動静脈の出 入りを認めた. 内部は粘绸度の高い白色不透明な液体で充満していた. 病理 診断は気管支性囊胞で, 囊胞は線毛円柱上皮に覆われ, 気管支腺や軟骨成分 を認めた，若干の文献的考察を含めて報告する。

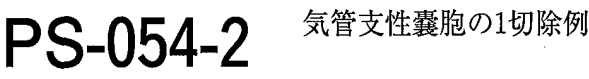

\section{鈴木 仁之, 田中 啓三, 金光 真治, 田中 仁, 伊藤 英樹}

安城更生病院胸部外科

我々は気管支性囊胞の1切除例を経験したので報告する，症例は49歳，男性. 28歳時に胸痛および発熱にて近医受診し，上縦隔腫瘍と診断されたが，数日 で腫瘍が急速に縮小したため外来フォローとなった，その後検診では毎年胸 部 X 線写真で異常陰影を指摘されていたが，自覚症状がないため定期的な フォローは受けていなかった，平成17年11月頃より，発熱と胸痛を頻回に認 めるようになったため，当院受診となった．CTにて食道左側と主気管支に 接する最大径 $70 \mathrm{~mm}$ の辺縁整・境界明瞭・内部均一で high density を呈す る類円形の腫瘤影を認めた，傍食道囊胞あるいは気管支性囊胞を疑い，診断 および治療目的で手術を施行した，腫瘍は左肺上葉内にも進展していたため 左肺上葉部分切除術も追加した．病変は暗紫色で混濁した内容液で充満した 囊胞で, 病理組織学的に Bronchogenic cyst と診断した. 気管支性囊胞は, 感染を繰り返すこと，および腺䍄発生という可能性を考慮し，手術的切除が 望ましいと思われる

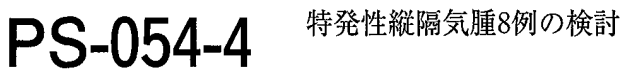

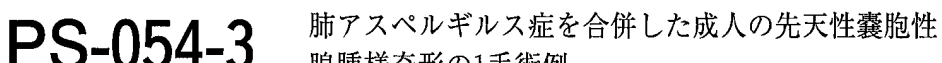 腺腫様奇形の1手術例}

\section{国立病院機構南京都病院呼吸器外科}

一瀨 増太郎, 朝倉 庄志, 大塩 恭彦

【はじめに】肺囊胞内にアスペルギルス感染を合併し喀血を呈したと考えられ る, 成人の先天性囊胞性腺腫様奇形 congenital cystic adenomatoid malformation (以下 CCAM)の稀な一症例を経験した。【症例】32歳女性. 2歳 時に肺炎の既往がある。検診で左下葉の空洞性病変を指摘. 胸部 CT にて左 下葉 $S^{10}$ に直径 $6 \mathrm{~cm}$ の巨大肺謈胞を認めた，経過観察されていたが，二年後 に揢血が出現し当院を紹介受診. 左 $\mathrm{S}^{10}$ の巨大肺囊胞は一年前に比し壁が肥 厚し内部に液体が貯留していた。 WBC 4800, CRP 0.1mg/dl と正常. $\beta$-D グルカン $20 \mathrm{pg} / \mathrm{ml}$ ，アスペルギルス抗原および沈降抗体は陰性. 血管造影で 左下横隔膜動脈から分枝して巨大肺囊胞の壁に流入する多数の異常動脈を確 認した。慢性炎症を伴った肺囊胞性疾患を疑い左肺下葉切除術を施行した。 病理組織像は巨大震胞の内埶が線毛上皮で被覆され，周囲に認める小型の囊 胞も線毛上皮細胞で被覆されていた. CCAM の type II と診断。培養は陰性 であったが囊胞内腔に菌塊を認めグロコット染色で菌塊内にアスペルギルス の菌系を認めた．肺アスペルギルス症と診断しミカファンギン $300 \mathrm{mg} を 40$ 日間点滴静注. 成人期に発見される CCAMの報告例は本症例を含め本邦で 6例と少なく，また真菌感染を合併した症例は検索し得た範囲で海外を含め 報告が無く極めて稀であると考えられた.【まとめ】成人期に発見された CCAMの稀な一症例を経験した. CCAM の霊胞にアスペルギルスによる感 染を合併し，喀血を呈したと考えられた.
${ }^{1}$ 新潟労㷋病院呼吸器外科, ${ }^{2}$ 産業医科大学第二外科

宗 哲哉 ${ }^{1}$ 能勢 直弘 ${ }^{1}$, 井上 政昭 ${ }^{1}$, 安元 公正 $^{2}$

【目的】明らかな原因疾患がなく突然発症する特発性縦隔気腫は比較的稀な疾 患とされている．今回，特発性縦隔気腫を8例経験したので，その臨床的背 景を検討した.【対象】2004年4月から2006年10月までの8例を対象とした。 【結果】性別は男性7例，女性1例であった。 8例中7例は発症年齢が10代後半で あり2例に自然気胸の既往を認め，1例は61歳男性で重契煙歷（40本/日 $\times 40$ 年間）を有する肺気腫合併症例であった。 また8例中5例は明らかな誘因を認 めなかったが，3例は誘因と考えられる運動（野球，バレー，テニス各1例ず つ）のエピソードを有していた，症状は胸痛が5例と多く，その他に頝部痛， 咳・呼吸苦, 嚥下時胸部違和感が各々 1 例ずつであった。触診にて䅡部皮下 気腫を 2 例に認めた，縦隔気腫の診断は胸部単純 X 線で6例は可能であった が，2例は胸部 CT で診断された。胸部 CTは6例に施行し, 縦隔気腫と皮下 気腫以外に有意病変を認めなかった．5例に気管支鏡検查を施行したがいず れも異常を認めなかった，治療は6例が入院安静となり，NSAIDs，抗生㓮 投与を行った．2例は外来で経過観察を行った．自覚症状は全例において治 療後1〜4日で改善を認め治瘉に至ったが，2例に再発を認めた.【結語】特発 性縦隔気腫の自覚症状は多彩であり, 頚部〜胸部症状を有する患者で考虑す ベき疾患の一つである. 本疾患は胸部単純 X 線で診断可能のことが多いが 描出されないこともある. Boerhaave' syndrome など他の鑑別すべき疾患 もあり，診断確定のために胸部 CT は有用である. 